\title{
Translational Control in the Brain in Health and Disease
}

\author{
Wayne S. Sossin ${ }^{1}$ and Mauro Costa-Mattioli ${ }^{2}$ \\ ${ }^{1}$ Montreal Neurological Institute, McGill University, Montreal, Quebec H3A-2B4, Canada \\ ${ }^{2}$ Department of Neuroscience, Memory and Brain Research Center, Baylor College of Medicine, Houston, \\ Texas 77030 \\ Correspondence: wayne.sossin@mcgill.ca; costamat@bcm.edu
}

Translational control in neurons is crucially required for long-lasting changes in synaptic function and memory storage. The importance of protein synthesis control to brain processes is underscored by the large number of neurological disorders in which translation rates are perturbed, such as autism and neurodegenerative disorders. Here we review the general principles of neuronal translation, focusing on the particular relevance of several key regulators of nervous system translation, including eukaryotic initiation factor $2 \alpha$ (elF2 $\alpha$ ), the mechanistic (or mammalian) target of rapamycin complex 1 (mTORC1), and the eukaryotic elongation factor 2 (eEF2). These pathways regulate the overall rate of protein synthesis in neurons and have selective effects on the translation of specific messenger RNAs (mRNAs). The importance of these general and specific translational control mechanisms is considered in the normal functioning of the nervous system, particularly during synaptic plasticity underlying memory, and in the context of neurological disorders.

\section{TRANSLATIONAL CONTROL IN MEMORY}

M emory storage is widely thought to have a physical basis in long-lasting changes in synaptic function (Malenka and Bear 2004; Mayford et al. 2012; Neves et al. 2008). For instance, high activity in a given neural pathway can persistently increase the efficacy of synaptic connections in a process called long-term potentiation (LTP). The reverse is also true: reduced activity persistently lowers synaptic efficacy, resulting in long-term depression (LTD). These long-lasting changes in synaptic strength are forms of synaptic plasticity and require de novo protein synthesis (Sutton and Schuman
2006; Costa-Mattioli et al. 2009; Trinh and Klann 2013; Buffington et al. 2014). Pioneering work by Josefa and Louis Flexner showed that short-lasting and longer-lasting memories are differentiated by the requirement for protein synthesis only for the latter (Flexner et al. 1967; Squire and Davis 1981). Thus, the requirement for new protein synthesis underlies long-lasting changes in both synaptic plasticity and memory.

However, despite more than 50 years of research in the field, several important questions remain unanswered: What are the major translational control programs regulating synaptic plasticity and memory storage? Where in the neuron is protein synthesis important for mem-

Editors: Michael B. Mathews, Nahum Sonenberg, and John W.B. Hershey

Additional Perspectives on Translation Mechanisms and Control available at www.cshperspectives.org

Copyright (C) 2019 Cold Spring Harbor Laboratory Press; all rights reserved; doi: 10.1101/cshperspect.a032912

Cite this article as Cold Spring Harb Perspect Biol 2019;11:a032912 
ory formation (cell soma vs. synapse; presynaptic axons vs. postsynaptic dendrites)? What is the nature of the messenger RNAs (mRNAs) whose translation is increased in response to a learning experience? Finally, is the translational control machinery dysregulated in cognitive disorders? If so, by specifically correcting the aberrant translational program, can we restore cognition in these brain disorders?

\section{GENERAL VERSUS SPECIFIC PROTEIN SYNTHESIS}

Two aspects of translational control are relevant for synaptic plasticity and memory: general translational control, which determines the overall rate of protein synthesis; and specific translational control, whereby selective regulatory mechanisms allow for translation of specific mRNAs.

When a memory is made, gene expression takes place selectively in a small number of neurons in a given brain area (Guzowski 2002; Reijmers and Mayford 2009). Growing evidence supports the idea that these are the neurons that encode the memory (Josselyn et al. 2015; Tonegawa et al. 2015). Currently, it is not known whether these neurons require (1) a general increase in translation, or (2) the translation of a specific subset of mRNAs to generate the long-lasting synaptic changes that encode memory.

Overall increases in the rate of protein synthesis after learning have been observed in a number of different learning paradigms (Davis and Squire 1984; Kelleher et al. 2004; Batista et al. 2016; Liu and Cline 2016). A general increase in translation rates could be important for the growth and stabilization of new synaptic connections formed in neurons that encode memory (Bailey and Kandel 2008; Xu et al. 2009; Yang et al. 2009; Ryan et al. 2015). The general activation of translation is associated with a number of processes that are discussed below, including decreased phosphorylation of the translation factors eukaryotic initiation factor (eIF) $2 \alpha$ and eukaryotic elongation factor 2 (eEF2) as well as activation of mechanistic target of rapamycin complex 1 (mTORC1).
By contrast, changes in the rate of translation of a subset of mRNAs may be sufficient for inducing or stabilizing changes at specific synapses. As we discuss below, the same pathways that regulate general translation can also regulate the synthesis of specific proteins. Thus, it is difficult to differentiate the relative importance of general and specific protein synthesis in the formation of a memory simply by identifying the regulatory pathway involved. Indeed, the two processes may be linked; for example, the specific translation of mRNAs with a $5^{\prime}$ terminal oligopyrimidine tract (TOP mRNAs) (Tsokas et al. 2007; Gobert et al. 2008) promotes general protein synthesis.

\section{DENDRITIC VERSUS SOMATIC PROTEIN SYNTHESIS}

Memory is thought to require the strengthening of a specific subset of synapses. The requirement for both protein synthesis and synapse specificity does not necessarily imply a requirement for the activation of translation locally at the synapses. Proteins can also be synthesized in the soma of a neuron and then selectively transported to synapses. Nevertheless, several lines of evidence support the notion that local translation is required for LTP and LTD (Sutton and Schuman 2006). More than 2000 mRNAs are found in synaptic processes (Cajigas et al. 2012), presumably through selective transport of these mRNAs, and increases in protein synthesis can be seen locally at synapses (Aakalu et al. 2001; Wang et al. 2009). Moreover, in some cases, protein synthesis-dependent LTP and LTD can be observed when the soma is physically disconnected from the synapse (Kang and Schuman 1996; Huber et al. 2000; Liu et al. 2003; Cracco et al. 2005; Gelinas and Nguyen 2005), supporting the notion that local translation can mediate long-lasting forms of synaptic plasticity. However, it is not entirely clear whether local translation is used for memory storage. Local application of protein synthesis inhibitors to synaptic regions decreases, but does not completely block, long-lasting forms of synaptic plasticity (Bradshaw et al. 2003). Local protein synthesis may be required to generate high concentrations 
of proteins locally at synapses to support basic synaptic functions (Cajigas et al. 2012), as opposed to the specific production of proteins to induce changes in synaptic plasticity. Indeed, many of the proteins that are known to be locally synthesized near synapses (e.g., calcium-calmodulin kinase II $\alpha$ [CAMKII $\alpha$ ], $\beta$-actin, and protein kinase $\mathrm{M} \zeta[\mathrm{PKM} \zeta])$ have high basal levels at synapses, and for at least one of these, CAMKII $\alpha$, the high basal levels require local protein synthesis (Miller et al. 2002). It is an open question how the small resultant change in concentration of these proteins can explain a functional change in synaptic strength. Furthermore, it is currently unknown how many out of the 2000 mRNAs found in synaptic processes are required for memory formation. In addition, so far, we have not been able to identify a translational control mechanism that takes place only at synapses (but not in the soma). Consequently, direct loss- or gain-of function evidence that local translation is required for memory consolidation is still missing. Even if local translation is required for the synaptic plasticity underlying memory, it is still unclear whether this requires selective translational control of a few mRNAs or a general increase in the translation of all transported mRNAs. These are important issues in the field that require further research.

\section{LATE-LTP AND SYNAPTIC TAGGING}

Even if local translation produces proteins only near activated synapses, protein diffusion would allow these proteins to be accessible to many synapses situated nearby in the same neuron (Rangaraju et al. 2017). Therefore, it is difficult to envision mechanisms for these proteins to act only at activated synapses in the absence of additional changes that restrict the actions of the new proteins to these synapses. Activation of protein synthesis is thus rarely sufficient to increase synaptic strength in the absence of other changes, a concept formalized in the "synaptic tagging" model (Frey and Morris 1998). In this model, the learning stimulus that generates memory leads to both (1) the translation of plasticity-related proteins (PRPs) in the neuron, and
(2) the formation of a "synaptic tag," which marks the activated synapse. The synaptic tag determines that the PRPs act only at the activated synapse. The production of PRPs is a conceptual framework that supports the necessity of specific protein synthesis for synaptic plasticity underlying memory but does not predict whether the PRPs are made locally or in the soma (Frey and Morris 1998).

There have been many suggestions to explain the molecular basis of the synaptic tag (Martin and Kosik 2002), including alterations in the actin cytoskeleton (Ramachandran and Frey 2009), slots for neurotransmitter-gated ion channels (Granger et al. 2013), and scaffold proteins that link persistently active kinases to their substrates (Hu et al. 2017). Candidates for the PRPs include persistently active kinases, such as truncated persistently active forms of protein kinase $\mathrm{C}$, termed PKM (Sajikumar et al. 2005) and phosphorylated, constitutively active CAMKII $\alpha$ (Sajikumar et al. 2007; Sanhueza and Lisman 2013). Other candidates include neurotransmitter-gated ion channels and immediate early genes such as Homer and activity-regulated cytoskeleton-associated protein (Arc) (Martin and Kosik 2002). PKM $\zeta$ (Muslimov et al. 2004; Eom et al. 2014), CAMKII $\alpha$ (Ouyang et al. 1999; Aakalu et al. 2001), neurotransmitter-gated channels (Ju et al. 2004), and Arc (Steward et al. 2014) have all been shown to be synthesized locally at or near the synapse after stimuli that produce long-lasting synaptic changes and memory, whereas Homer is synthesized only in the soma (Okada et al. 2009).

\section{PRESYNAPTIC VERSUS POSTSYNAPTIC PROTEIN SYNTHESIS}

The vast majority of the work on neuronal protein synthesis has focused on local translation in the dendrite, the postsynaptic region of the neuron. These studies are driven by the assumption that ribosomes travel down dendrites, but not down axons to the presynaptic region of the cell. Indeed, the main evidence against presynaptic protein synthesis is the failure to visualize polysomes in presynaptic endings in electron microscopic (EM) studies (Twiss and Fainzilber 
W.S. Sossin and M. Costa-Mattioli

2009). However, emerging evidence supports the notion that presynaptic protein synthesis is also important for synaptic plasticity. First, many studies have shown that during development, local translation in axonal growth cones is important for axon guidance, and in mature neurons local translation in the axon is important for response to injury (Jung et al. 2012). In GABAergic neurons, presynaptic protein synthesis is required for long-term plasticity (Younts et al. 2016). In invertebrates, many forms of plasticity depend on presynaptic protein synthesis (Martin et al. 2000; Costa-Mattioli et al. 2009). More recently, surveys of mRNAs found in the synaptic region have shown abundant presence of mRNAs for presynaptic proteins (Cajigas et al. 2012). Finally, whereas it has been difficult to identify polyribosomes at presynaptic sites by EM (Buxbaum et al. 2014), ribosomes and polysomes have been found in presynaptic endings from squid by electron spectroscopy and $\left[{ }^{3} \mathrm{H}\right]$-leucine labeling (Crispino et al. 1997). In future experiments, it would be interesting to determine whether the same translational control mechanisms operate in presynaptic and postsynaptic compartments.

\section{eIF2 $\alpha$-MEDIATED TRANSLATION: A MEMORY SWITCH}

As discussed above, making new proteins is a critical step required for the generation of longlasting memories. In particular, the eIF $2 \alpha$ signaling pathway plays a dominant role in regulating memory formation. Phosphorylation of the $\alpha$ subunit of eIF2 at Ser51 is tightly regulated by four kinases: (1) the heme-regulated kinase HRI; (2) the double-strand RNA-dependent protein kinase R (PKR); (3) the PKR-like endoplasmic reticulum kinase (PERK); and (4) the highly conserved kinase general control nonderepressible 2 (GCN2). Dephosphorylation of eIF2 $\alpha$ is regulated by two phosphatase complexes: (1) the catalytic subunit protein phosphatase 1 (PP1) and the regulatory subunit PPP1R15A/ GADD34, and (2) PP1 and the regulatory protein PPP1R15B/CReP (Fig. 1A) (Merrick and Pavitt 2018; Wek 2018). Behavioral training leads to a decrease in the phosphorylation of eIF2 $\alpha$ in the hippocampus (Costa-Mattioli et al. 2007), a brain structure crucially required for memory formation (Squire et al. 2015). Accordingly, heterozygous eIF $2 \alpha^{\mathrm{S} / \mathrm{A}}$ knock-in mice (where the single phosphorylation site at serine 51 is replaced by alanine in one allele), with reduced phosphorylation of eIF2 $\alpha$ in the hippocampus, show enhanced memory in a variety of behavioral tasks (Costa-Mattioli et al. 2007), indicating that eIF $2 \alpha$ phosphorylation normally serves as a memory repressor. Consistent with the results of the eIF $2 \alpha^{\text {S/A }}$ knock-in mice, genetic deletion of any of the eIF2 $\alpha$ kinases expressed in the brain, GCN2, PKR, or PERK, enhances memory formation (Costa-Mattioli et al. 2005, 2007; Zhu et al. 2011; Stern et al. 2013; Ounallah-Saad et al. 2014). However, using conditional knockout mice in which PERK is removed only in the forebrain, deficits in behavior including increased repetitive behaviors and behavioral inflexibility were observed (Trinh et al. 2012). We speculate that this may be because PERK phosphorylates targets other than eIF $2 \alpha$ and/or mod-

Figure 1. Eukaryotic initiation factor (eIF) $2 \alpha$ bidirectionally regulates the two major forms of plasticity, longterm potentiation (LTP) and long-term depression (LTD) in the brain. ( $A$ ) Regulation of translation by eIF2 $\alpha$ phosphorylation. (B) Increased eIF2 $\alpha$ phosphorylation prevents long-lasting LTP induced by four trains of highfrequency stimulation (arrows), but facilitates metabotropic glutamate receptors (mGLuRs)-LTD. The strength of the synapse is measured by postsynaptic potentials (PSPs), or excitatory postsynaptic currents (ePSCs) normalized to the strength before induction of LTP or mGLuR-LTD, respectively. $(C)$ Decreased eIF2 $\alpha$ phosphorylation facilitates LTP induced by one high frequency stimulation but blocks mGLuR-induced LTD. The strength of the synapse is measured by PSPs or ePSCs normalized to the strength before induction of LTP or mGLuR-LTD, respectively. PKR, Protein kinase R; GCN2, general control nonderepressible 2; PERK, PKR-like endoplasmic reticulum kinase; PP1, protein phosphatase 1; mRNA, messenger RNA; uORF, upstream open reading frames; UTR, untranslated region. 

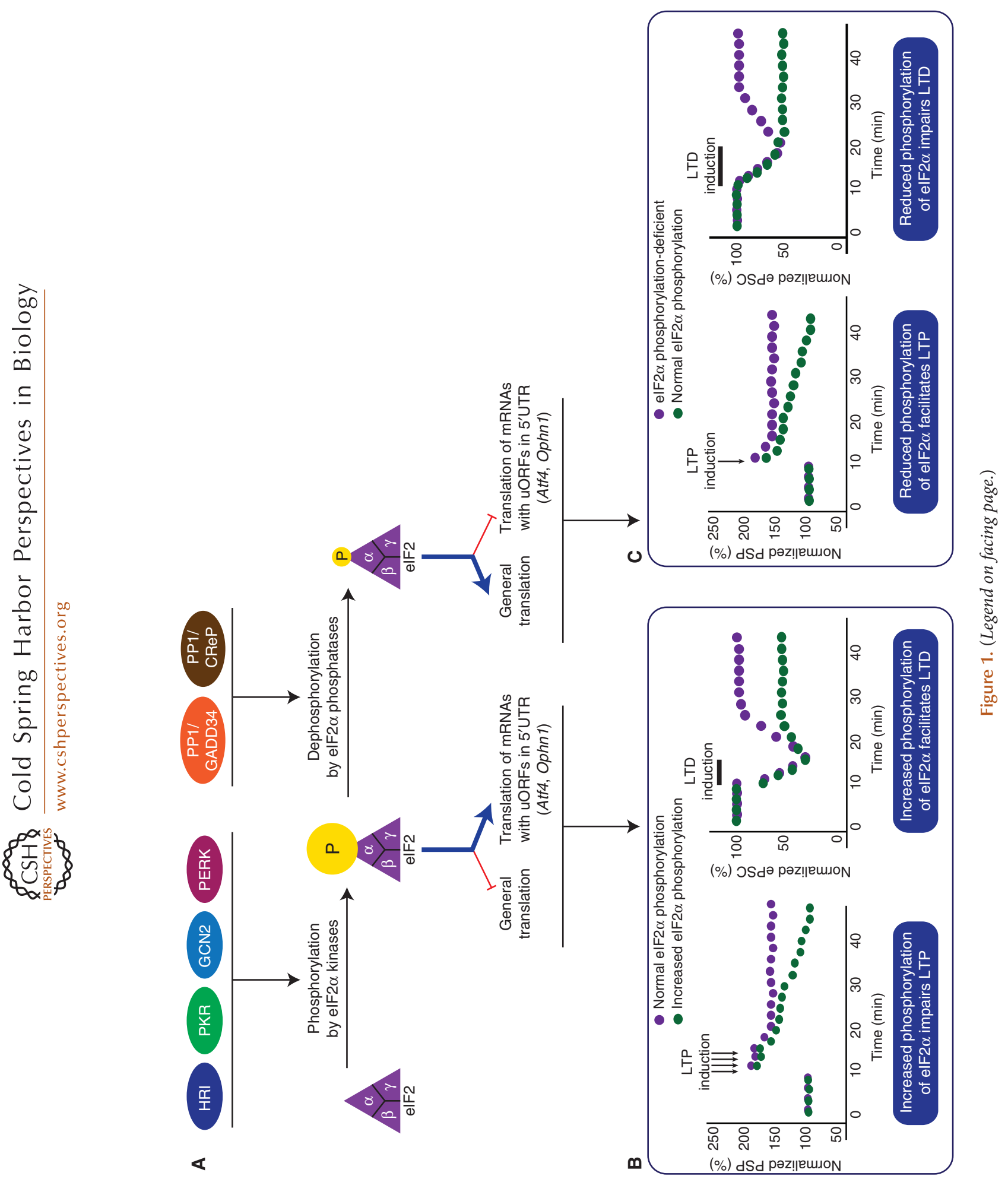
ulates calcium dynamics (Zhu et al. 2016), because these perturbations have not been seen in the heterozygous eIF $2 \alpha^{\mathrm{S} / \mathrm{A}}$ knock-in mice. Indeed, several targets of PERK other than eIF2 $\alpha$ that may regulate synaptic plasticity have recently been identified including CREB (Sen et al. 2017), calcineurin (Wang et al. 2013), and endoplasmic reticulum(ER)-mitochondrial tethering (van Vliet et al. 2016).

Pharmacological experiments also support the notion that eIF $2 \alpha$ phosphorylation is a memory suppressor. Pharmacological inhibition of either (1) PKR with a specific inhibitor (PKRi), or (2) derepression of the translational program controlled by eIF $2 \alpha$ with a recently discovered small-molecule inhibitor (integrated stress response inhibitor [ISRIB]), enhances memory formation in both mice and chicks (Zhu et al. 2011; Sidrauski et al. 2013; Stern et al. 2013; Batista et al. 2016), highlighting the evolutionarily conserved role of the eIF $2 \alpha$ signaling pathway in learning and memory. Thus, convergent genetic and pharmacological manipulations provide strong evidence that derepression of the translational program controlled by eIF $2 \alpha$ is sufficient to enhance memory.

The opposite is also true: increased eIF2 $\alpha$ phosphorylation in the brain impairs longterm memory. Administration of Sal003, an inhibitor of eIF $2 \alpha$ phosphatases, increases eIF $2 \alpha$ phosphorylation in both mice and chicks and prevents their ability to form long-term memory (Costa-Mattioli et al. 2007; Batista et al. 2016). Moreover, using an elegant phamacogenetic approach to allow specific activation of engineered PKR in the hippocampus, Jiang and coworkers (2010) showed that increasing eIF $2 \alpha$ phosphorylation only in CA1 neurons of the mouse hippocampus was sufficient to block long-term memory. Importantly, in this study, the pharmacogenetic manipulation of eIF2 $\alpha$ phosphorylation did not affect general translation. In contrast, local application of low-dose anisomycin to the CA1 region significantly decreased overall translation without blocking memory formation. Thus, in this model, a strong argument could be made that specific translational changes downstream of eIF $2 \alpha$ phosphorylation are required for memory, as opposed to a requirement for a general increase in translation.

During LTP, eIF2 $\alpha$ phosphorylation is reduced (Costa-Mattioli et al. 2005, 2007). However, an increase in eIF $2 \alpha$ phosphorylation occurs during a protein synthesis-dependent form of LTD associated with activation of metabotropic glutamate receptors, termed mGluRLTD (Di Prisco et al. 2014; Trinh et al. 2014). Indeed, genetic reduction of eIF $2 \alpha$ phosphorylation (or treatment with ISRIB) enhances LTP (Costa-Mattioli et al. 2007; Zhu et al. 2011; Huang et al. 2016; Placzek et al. 2016) but blocks mGluR-LTD (Fig. 1B) (Di Prisco et al. 2014). By contrast, increased eIF2 $\alpha$ phosphorylation impairs LTP (Costa-Mattioli et al. 2007; Jiang et al. 2010; Huang et al. 2016) but induces mGluRLTD (Fig. 1C) (Di Prisco et al. 2014). Taken together, eIF2 $\alpha$ phosphorylation bidirectionally controls two major forms of synaptic plasticity (LTP and LTD) and is thus crucial for memory formation.

Some of the proteins regulated by phosphorylation of eIF2 $\alpha$ during memory formation have been identified, including ATF4 (Costa-Mattioli et al. 2007) and oligophrenin-1 (OPHN1) (Di Prisco et al. 2014). Similar to other situations where eIF2 $\alpha$ regulation is important, these mRNAs contain upstream open reading frames (uORFs) in their $5^{\prime}$ untranslated region (UTR) (Hinnebusch et al. 2016). However, there has not yet been a systematic examination of all the mRNAs in neurons that are regulated by the eIF2 $\alpha$ pathway in the brain. The use of translating ribosome affinity purification (Heiman et al. 2008), ribosome profiling (Ingolia et al. 2018), or a combination of both methods, will help to elucidate the translational state regulated by phosphorylation of eIF $2 \alpha$ in the brain.

\section{TRANSLATIONAL CONTROL BY mTORC1}

Treatment with the highly specific mTORC1 inhibitor, rapamycin (Tang et al. 2002; Bekinschtein et al. 2007) or direct pharmacogenetic inhibition of mTORC1 (Stoica et al. 2011) prevents the ability to elicit long-lasting LTP and form long-term memory (Costa-Mattioli and Monteggia 2013). mTORC1 integrates information 
from various synaptic inputs and is believed to control the formation of memory by regulating translation via S6 kinase (S6K) and eIF4Ebinding proteins (4E-BPs) (Sonenberg and Hinnebusch 2009; Proud 2018). S6K regulates translation initiation and elongation through phosphorylation of eukaryotic initiation factor 4B (eIF4B) and eEF2 kinase (eEF2K), respectively. By contrast, 4E-BPs exclusively repress translation initiation through binding to eIF4E. Although inhibition of mTORC1 blocks memory formation, activation of mTORC1 does not enhance memory formation (Graber et al. 2013). This is in contrast to eIF $2 \alpha$ phosphorylation, where as described above, memory formation is facilitated when levels of eIF $2 \alpha$ are reduced. Gain-of-function activation of mTORC1 by inhibiting upstream suppressors of mTORC1, tuberous sclerosis complex (Tsc) or phosphatase and tensin homolog (Pten), impairs, not enhances, synaptic plasticity and memory formation (von der Brelie et al. 2006; Ehninger et al. 2008; Sperow et al. 2012; Lugo et al. 2013). Similarly, whereas mice lacking 4E$\mathrm{BP} 2$, the major 4E-BP isoform in the brain, show a lowered threshold for the induction of LTP (Banko et al. 2005), under normal learning conditions, 4E-BP2-deficient mice show impaired LTP and long-term memory (Banko et al. 2005). Thus, the correct balance of mTORC1 activation seems critical for normal memory formation.

The cap-binding factor eIF4E is normally inhibited by nonphosphorylated 4E-BPs (Sonenberg and Hinnebusch 2009). In nonneuronal cells, activation of mTORC1 promotes translation rates via phosphorylation of $4 \mathrm{E}-\mathrm{BPs}$ (Hsieh et al. 2012; Thoreen et al. 2012; Proud 2018). However, in the adult brain, there are only low levels of phosphorylated 4E-BP2 (Bidinosti et al. 2009), the major 4E-BP form. The low levels of phosphorylation are associated with increased deamidation of $4 \mathrm{E}-\mathrm{BP} 2$, which increases its association with the mTORC1 adaptor raptor, although the significance of this enhanced binding is still unclear (Bidinosti et al. 2009). Thus, it is unclear whether mTORC1 regulates translation in the adult brain through phosphorylation of $4 \mathrm{E}-\mathrm{BPs}$. It should also be noted that
mTORC1 regulates a variety of biological processes other than protein synthesis, including autophagy, metabolism, and lipid metabolism biosynthesis (Wullschleger et al. 2006; Laplante and Sabatini 2012). Thus, it is not yet clear whether mTORC1 regulates memory formation by controlling protein synthesis or other biological processes.

\section{REGULATION OF TRANSLATION ELONGATION}

Interest in the role of regulating translational elongation in the nervous system has increased in recent years (Taha et al. 2013; Richter and Coller 2015). Although we have a good understanding of how translation initiation of specific mRNAs can be regulated by uORFs, structured $5^{\prime}$ UTRs, and interactions between RNA-binding proteins and the initiation machinery (Sossin and Lacaille 2010; Darnell and Richter 2012), the role of elongation in controlling translation of specific transcripts is less clear.

There are two major elongation factors, the GTPases eEF1 and eEF2. eEF1 is comprised of eEF1A and eEF1B; eEF1A recruits aminoacylated transfer RNAs (tRNAs) to the A site in the ribosome and is complexed with eEF1B, its guanine nucleotide exchange factor (GEF) (Sasikumar et al. 2012). The translation of eEF1A mRNA is regulated by a TOP sequence in its $5^{\prime}$ UTR. In neurons, eEF1A mRNA is translated locally at dendrites during memory formation and synaptic plasticity (Giustetto et al. 2003; Huang et al. 2005; Tsokas et al. 2005).

In contrast to eEF1, eEF2 is one of the few GTPases that does not require a GEF for activation. eEF2 ratchets the peptidyl-tRNA from the hybrid position on the ribosome after peptide bond formation to the P-site position (Kaul et al. 2011; Dever et al. 2018). There are reports of increased synthesis of eEF2 after induction of synaptic plasticity (Carroll et al. 2004; Takei et al. 2009) and eEF2, like eEF1A, is regulated through a TOP motif. Thus, because TOP mRNAs are regulated downstream of the $\mathrm{mTORC} 1$ pathway, one mechanism for mTORC1 regulation of elongation could be through increasing levels of elongation factors. 
W.S. Sossin and M. Costa-Mattioli

\section{REGULATION OF ELONGATION THROUGH eEF2K}

Much attention has been devoted to studying eEF2 phosphorylation at Thr57 by eEF2K (Nairn and Palfrey 1987; Proud 2015; Dever et al. 2018). No other kinase appears to phosphorylate eEF2 at this site, as there is a complete lack of detectable eEF2 phosphorylation when eEF2K is genetically ablated (Heise et al. 2017). Phosphorylation of eEF2 reduces its binding to the ribosome and thus decreases elongation (Proud 2015, 2018). The impact of eEF2 phosphorylation on translation depends on whether (1) the rate of elongation is rate-limiting for translation overall, (2) the levels of eEF2 are rate-limiting for elongation, and (3) the extent of eEF2 phosphorylation. Increasing levels of eEF2 in cultured neurons decreased elongation times and increased protein synthesis, suggesting that eEF2 levels can be rate-limiting in neurons under some circumstances (Takei et al. 2009). However, increasing levels of active eEF2 by eliminating eEF2 phosphorylation through removal of eEF2K did not change the overall rate of protein synthesis in the brain (Heise et al. 2017).

A decrease in eEF2 phosphorylation in the hippocampus occurs after fear conditioning and after induction of long-term increases in synaptic strength in Aplysia neurons (Im et al. 2009; McCamphill et al. 2015). Preventing the decrease in eEF2 phosphorylation blocks longterm increases in synaptic strength in Aplysia (McCamphill et al. 2017), demonstrating that eEF2 dephosphorylation is required for longterm facilitation. Accordingly, in mice lacking eEF2K and with decreased eEF2 phosphorylation, long-term fear memory is impaired (Heise et al. 2017).

eEF2 phosphorylation is regulated by mTORC1 (Carroll et al. 2004; Inamura et al. 2005; McCamphill et al. 2015) through a conserved S6K phosphorylation site in eEF2K that inactivates the kinase (Wang et al. 2001; Weatherill et al. 2011). This site can also be phosphorylated by ERK through RSK2 (Wang et al. 2001).

Increased eEF2 phosphorylation has been shown in a number of synaptic plasticity and learning procedures, including novel taste learn- ing (Belelovsky et al. 2005), LTP in the dentate gyrus (Panja et al. 2009), mGluR-LTD (Park et al. 2008), and a form of intermediate facilitation in Aplysia (McCamphill et al. 2015). Preventing the increase in eEF2 phosphorylation blocks both mGluR-LTD (Park et al. 2008) and intermediate facilitation in Aplysia (McCamphill et al. 2015), but eEF2 phosphorylation does not appear to be required for LTP in the dentate gyrus (Panja et al. 2009). It is not clear whether the increased eEF2 phosphorylation inhibits overall translation elongation rates in these situations, but it has been shown to be required for the increased translation of specific mRNAs including CAMKII $\alpha$, brain-derived neurotrophic factor (BDNF), microtubule-associated protein (Map)1B and other cytoskeletal proteins (Fig. 2) (Scheetz et al. 2000; Davidkova and Carroll 2007; Park et al. 2008; Verpelli et al. 2010; Kenney et al. 2016; Heise et al. 2017).

There are two proposed mechanisms by which increased eEF2 phosphorylation could lead to the up-regulation of translation of specific mRNAs. When elongation is slow, the ribosome is slow to clear the initiation site; this decreases the rate of initiation on well-translated mRNAs, freeing rate-limiting initiation factors (reviewed in Sossin and Lacaille 2010). The second proposed mechanism involves eEF2 phosphorylation, which plays a role in the release of stalled polysomes. This proposal arose because of a correlation between synaptic plasticity events that specifically require eEF2 phosphorylation and those that are mediated by initiation-independent translation (i.e., forms of plasticity that are blocked by elongation inhibitors and resistant to translation inhibitors; see McCamphill et al. 2015). These forms of plasticity include mGluR-LTD in hippocampal neurons (Graber et al. 2013) and intermediate facilitation in Aplysia neurons (McCamphill et al. 2015).

Stalled polysomes have been suggested as an important mechanism for regulated transport of mRNAs to the synapse (Sossin and DesGroseillers 2006). mRNA initiation takes place in the cell soma; at some point elongation is stalled, and the stalled polysome is packaged into an RNA granule that is then transported to the syn- 


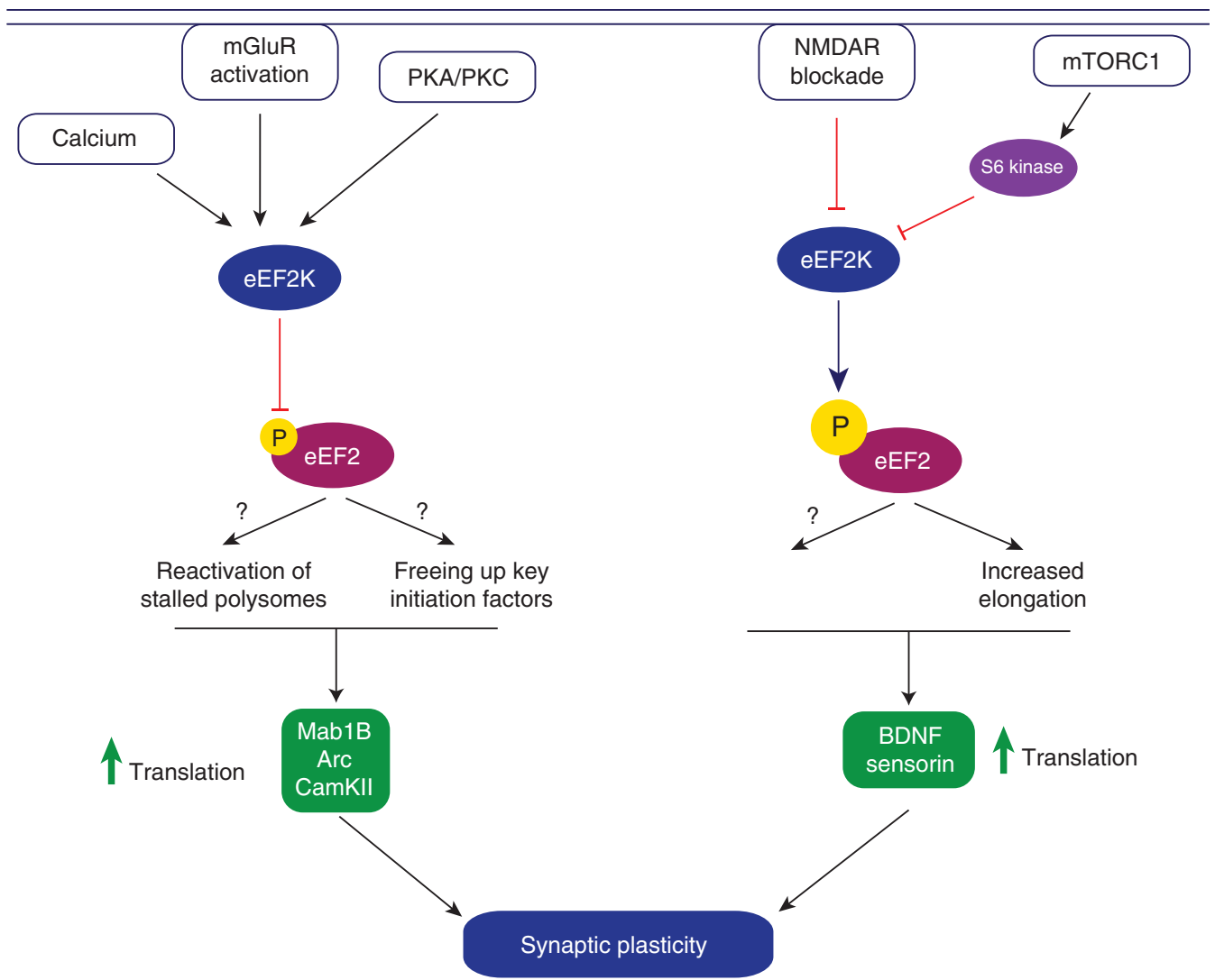

Figure 2. Upstream and downstream of eukaryotic elongation factor 2 (eEF2) phosphorylation. In neurons, eukaryotic elongation factor 2 kinase $(\mathrm{eEF} 2 \mathrm{~K})$ can be activated by calcium influx, metabotropic glutamate receptor (mGLuR) activation, or protein kinases. The resultant increase in eEF2 phosphorylation increases translation of selective transcripts either by freeing up key initiation factors or by reactivating stalled polysomes. The increased synthesis of these proteins is linked to changes in synaptic strength (synaptic plasticity). In contrast, blockade of the $N$-methyl-D-aspartate receptor (NMDAR) or activation of the S6 kinase downstream of target of rapamycin complex 1 (TORC1) leads to a decrease in the activity of eEF2K. The resultant decrease in eEF2 phosphorylation causes an overall increased elongation rate with specific increases in the synthesis of several secreted factors, such as brain-derived neurotrophic factor (BDNF) in vertebrates and sensorin in Aplysia. The increased synthesis of these factors is linked to protein synthesis-dependent increases in synaptic strength (synaptic plasticity). PKA, Protein kinase A; PKC, protein kinase C.

apse. After the stall is relieved, translation from previously stalled polysomes is dependent only on elongation, but not initiation, similar to the forms of plasticity that require eEF2 phoshorylation noted above. The fragile $\mathrm{X}$ mental retardation protein (FMRP), the protein lost in fragile $\mathrm{X}$ syndrome in humans, is associated with stalled polysomes (Mazroui et al. 2002; Darnell et al. 2011; El Fatimy et al. 2016). FMRP can stall polysomes through direct binding to ribosomal RNA (Chen et al. 2014). The role of FMRP in stalling polysomes is consistent with the role of FMRP in regulating mGLuR-LTD (Hou et al. 2006; Nosyreva and Huber 2006; Graber et al. 2017). However, how phosphorylation of eEF2 regulates stalled polysomes is not immediately clear. One possibility is that the inactive phosphorylated form of eEF2 plays a role in stalling, and removal of this inactive form through eEF2 dephosphorylation is required for unstalling.

If mRNAs are transported to synapses in stalled polysomes, these polysomes would need 
W.S. Sossin and M. Costa-Mattioli

to be protected from the ribosome-associated quality-control pathway that rescues stalled polysomes (Buskirk and Green 2017). Indeed, this rescue pathway is particularly important when levels of rare charged tRNAs are low, and the absence of this rescue pathway leads to neuronal degeneration (Ishimura et al. 2014). This may indicate that ribosomes are a limiting resource in neurons, which would be consistent with stalled polysomes, sequestering many of the ribosomes in dendrites and thus making the number of ribosomes rate-limiting for basal translation. A study examining changes in polysomes after learning (Ostroff et al. 2017) identified polysomes that are both sensitive and resistant to the initiation inhibitor 4EGI-1, which blocks the association of eIF4E and eIF4G, which is required for cap-dependent translation (Moerke et al. 2007). In this study, the sensitive and resistant polysomes were differentially distributed at distinct types of synapses (Ostroff et al. 2017). It was unclear in this study, however, whether the 4EGI-1-resistant polysomes were stalled or initiated in a cap-independent (and thus 4EGI-1-independent) manner.

\section{TRANSLATIONAL CONTROL AND NEURODEVELOPMENTAL DISORDERS}

Genetic perturbations impinging on translational control mechanisms have been associated with developmental disorders of the nervous system. In the last few years, it has been shown that specific translational control mechanisms are perturbed in these cases. The questions to be addressed are (1) whether restoration of translation reverses the cognitive decline in these disorders, and (2) whether drugs can be developed to target translation in the treatment of brain disorders.

\section{PERTURBED TRANSLATIONAL CONTROL IN NEUROLOGICAL DISORDERS}

How dysregulation of the signaling pathways impinging on translation contributes to the pathophysiology of several neurodegenerative diseases and neurodevelopmental disorders has been recently reviewed (Buffington et al.
2014; Huber et al. 2015; Kapur et al. 2017). One important context of translational regulation in neurological disorders is autism spectrum disorders (ASDs). The importance of translational control in ASD is underscored by the many neurological disorders in which mTORC1 activity is perturbed as a result of single gene mutations in mTORC1 upstream regulators (Pten, Tsc, or Fmr1). Indeed, in all three cases, enhanced translation rates have been postulated to cause ASD (Kelleher and Bear 2008). However, deletion of Pten or Tsc not only activates mTORC1, but also alters mTORC2 activity (Laplante and Sabatini 2012). Because mTORC2 is also required for LTP and mnemonic processes (Huang et al. 2013), it is currently unclear which mTOR complex drives the ASD pathology in these TORopathies. In addition, as we mentioned above, mTORC1 regulates other translation-independent processes (Proud 2018).

The strongest evidence that translation upregulation leads to ASD-like behaviors emerged from studies of mice lacking 4E-BPs or overexpressing eIF4E. In both models, increased eIF4E-mediated translation leads to ASD-like behaviors (Gkogkas et al. 2013; Santini et al. 2013). Moreover, agents that modestly decrease translation rates, like rapamycin, metformin, or an inhibitor of the eIF4E kinase, MNK1, reverse ASD-like behaviors in FMRP-deficient mice (Busquets-Garcia et al. 2013; Gkogkas et al. 2014; Gantois et al. 2017), supporting the notion that enhanced overall translation contributes to the pathology associated with fragile $\mathrm{X}$ syndrome. Although most of these studies rescued the phenotypes in Fmr1-deficient mice by repressing initiation, in one study, reduction of the RNA-binding protein CPEB rescued pathology in Fmr1-deficient mice and this was associated with normalization of translation elongation rates (Udagawa et al. 2013).

These data suggest that increased translation may cause neuronal dysfunction in the fragile $\mathrm{X}$ syndrome. Accordingly, deletion of 4E-BP2 leads to an increase in the synthesis of the synaptic adhesion protein neuroligin-1, and preventing this increase ameliorates autistic-like behaviors in this rodent model (Gkogkas et al. 
2013). Matrix metalloprotease 9 (Mmp9) is overexpressed in fragile $\mathrm{X}$ mice and decreasing its translation through reducing eIF4E phosphorylation rescues several autistic-like behaviors in this model (Gkogkas et al. 2014).

The second context in which translation dysregulation has been observed is neurodegenerative disease. In this case, a decrease in translation rates was reported in Alzheimer's disease (AD) (Langstrom et al. 1989), likely because of the activation of the integrated stress response (ISR), wherein eIF2 $\alpha$ phosphorylation is a central component (Wek 2018). Increased phosphorylation of eIF $2 \alpha$ has been observed in AD (Chang et al. 2002a,b; Hoozemans et al. 2005; Page et al. 2006), traumatic brain injury (Dash et al. 2015; Chou et al. 2017), and prion disease (Moreno et al. 2012). It is currently unclear whether translation dysregulation underlies, or is a downstream effector of, neurodegenerative disease. Nevertheless, increasing translation could ameliorate the disease. Indeed, both genetic reduction of eIF2 $\alpha$ phosphorylation (PKR or PERK knockout mice and GADD34-overexpressing vectors) or pharmacological correction of the abnormal translational program controlled by eIF $2 \alpha$ (e.g., using ISRIB and PKR inhibitors) reverses the cognitive decline associated with AD (Lourenco et al. 2013; Ma et al. 2013; Segev et al. 2015), traumatic brain injury (Chou et al. 2017), as well as the pathology associated with prion disease (Moreno et al. 2012).

Recently, eEF2 phosphorylation has also been reported to be elevated both in mouse models of $\mathrm{AD}$ and $\mathrm{AD}$ patients (Ma et al. 2014). Inhibiting eEF2K restored LTP that had been inhibited by $\beta$ amyloid (Ma et al. 2014).

mTOR complexes have also been proposed to be targets for neurodegenerative diseases (Santos et al. 2011), although the proposed role for mTOR in neurodegenerative disease has mainly been through mTOR regulation of autophagy as opposed to direct regulation of protein synthesis.

Thus, perturbed eIF2 $\alpha$ phosphorylation (and possibly eEF2 phosphorylation), is responsible, at least in part, for some of the cognitive and cellular aspects underlying neurodegenerative disorders. Neurodegenerative diseases are also caused by expansions of nucleotide repeats in proteins and these may also have an important contribution from dysregulated translation centered on those nucleotide repeats ( $\mathrm{Zu}$ et al. 2018), further emphasizing the importance of translational control in neuronal disease.

\section{CONCLUDING REMARKS}

Regulation of mRNA translation initiation and elongation is essential for synaptic plasticity and memory formation. Moreover, alterations in translation rates resulting from mutations in signaling pathways regulating translation or activation of the ISR contribute to pathogenesis in a variety of neurological disorders. One of the most intriguing questions in the memory field, the identification of the nature of the proteins that are synthesized in response to a memory paradigm, remains largely unanswered. Given that memory is encoded in a small subset of neurons in a particular brain area, answering this question will require state-of-the-art intersectional molecular genetic approaches combined with translating ribosome affinity purification (TRAP) in the specific neurons that encode memories.

A better understanding of translational control in brain processes will require a full dissection at the cell-type level. The formation of memory is not only mediated by principal (pyramidal) neurons in a given brain area. In fact, other neuronal cell types, such as inhibitory or dopaminergic neurons, are crucially involved in memory formation. However, understanding the regulation of translation in these cell types is just beginning (Ran et al. 2009; Placzek et al. 2016).

From a therapeutic standpoint, it would be interesting to determine whether some of the very promising genetic manipulations blocking or activating translation can be replicated using pharmacology. Pharmacological agents that modulate translation rates by regulating the integrated stress response, such as PKRi and ISRIB, have been identified and initial results suggest the usefulness of these drugs in improving cognition (Zhu et al. 2011; Sidrauski et al. 2013; Chou et al. 2017). Their efficacy in multi- 
W.S. Sossin and M. Costa-Mattioli

ple mouse models of disease remains to be examined before considering whether these drugs can be used to treat human disease. Drugs that act on other targets, including downstream effectors of TORC1, regulators of stalled polysomes, and inhibitors and activators of eEF2K are also interesting candidates for ameliorating disease.

\section{REFERENCES}

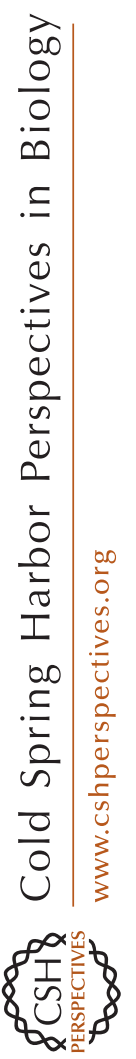

${ }^{*}$ Reference is also in this collection.

Aakalu G, Smith WB, Nguyen N, Jiang C, Schuman EM. 2001. Dynamic visualization of local protein synthesis in hippocampal neurons. Neuron 30: 489-502.

Bailey CH, Kandel ER. 2008. Synaptic remodeling, synaptic growth and the storage of long-term memory in Aplysia. Prog Brain Res 169: 179-198.

Banko JL, Poulin F, Hou L, DeMaria CT, Sonenberg N, Klann E. 2005. The translation repressor 4E-BP2 is critical for eIF4F complex formation, synaptic plasticity, and memory in the hippocampus. J Neurosci 25: 95819590.

Batista G, Johnson JL, Dominguez E, Costa-Mattioli M, Pena JL. 2016. Translational control of auditory imprinting and structural plasticity by eIF2 $\alpha$. eLife 5: e17197.

Bekinschtein P, Katche C, Slipczuk LN, Igaz LM, Cammarota M, Izquierdo I, Medina JH. 2007. mTOR signaling in the hippocampus is necessary for memory formation. Neurobiol Learn Mem 87: 303-307.

Belelovsky K, Elkobi A, Kaphzan H, Nairn AC, Rosenblum K. 2005. A molecular switch for translational control in taste memory consolidation. Eur J Neurosci 22: 25602568.

Bidinosti M, Ran I, Sanchez-Carbente MR, Martineau Y, Gingras AC, Gkogkas C, Raught B, Bramham CR, Sossin WS, Costa-Mattioli M, et al. 2009. Postnatal deamidation of $4 \mathrm{E}-\mathrm{BP} 2$ in brain enhances its association with raptor and alters kinetics of excitatory synaptic transmission. Mol Cell 37: 797-808.

Bradshaw KD, Emptage NJ, Bliss TV. 2003. A role for dendritic protein synthesis in hippocampal late LTP. Eur J Neurosci 18: 3150-3152.

Buffington SA, Huang W, Costa-Mattioli M. 2014. Translational control in synaptic plasticity and cognitive dysfunction. Annu Rev Neurosci 37: 17-38.

Buskirk AR, Green R. 2017. Ribosome pausing, arrest and rescue in bacteria and eukaryotes. Philos Trans $R$ Soc Lond B Biol Sci 372: 20160183.

Busquets-Garcia A, Gomis-Gonzalez M, Guegan T, AgustinPavon C, Pastor A, Mato S, Perez-Samartin A, Matute C, de la Torre R, Dierssen M, et al. 2013. Targeting the endocannabinoid system in the treatment of fragile $\mathrm{X}$ syndrome. Nat Med 19: 603-607.

Buxbaum AR, Wu B, Singer RH. 2014. Single $\beta$-actin mRNA detection in neurons reveals a mechanism for regulating its translatability. Science 343: 419-422.
Cajigas IJ, Tushev G, Will TJ, tom Dieck S, Fuerst N, Schuman EM. 2012. The local transcriptome in the synaptic neuropil revealed by deep sequencing and high-resolution imaging. Neuron 74: 453-466.

Carroll M, Warren O, Fan X, Sossin WS. 2004. 5-HT stimulates eEF2 dephosphorylation in a rapamycin-sensitive manner in Aplysia neurites. J Neurochem 90: $1464-$ 1476.

Chang RC, Suen KC, Ma CH, Elyaman W, Ng HK, Hugon J. 2002a. Involvement of double-stranded RNA-dependent protein kinase and phosphorylation of eukaryotic initiation factor- $2 \alpha$ in neuronal degeneration. J Neurochem 83 : $1215-1225$.

Chang RC, Wong AK, Ng HK, Hugon J. 2002b. Phosphorylation of eukaryotic initiation factor- $2 \alpha(\mathrm{eIF} 2 \alpha)$ is associated with neuronal degeneration in Alzheimer's disease. Neuroreport 13: 2429-2432.

Chen E, Sharma MR, Shi X, Agrawal RK, Joseph S. 2014. Fragile X mental retardation protein regulates translation by binding directly to the ribosome. Mol Cell 54: 407-417.

Chou A, Krukowski K, Jopson T, Zhu PJ, Costa-Mattioli M, Walter P, Rosi S. 2017. Inhibition of the integrated stress response reverses cognitive deficits after traumatic brain injury. Proc Natl Acad Sci 114: E6420-E6426.

Costa-Mattioli M, Monteggia LM. 2013. mTOR complexes in neurodevelopmental and neuropsychiatric disorders. Nat Neurosci 16: 1537-1543.

Costa-Mattioli M, Gobert D, Harding H, Herdy B, Azzi M, Bruno M, Bidinosti M, Ben Mamou C, Marcinkiewicz E, Yoshida M, et al. 2005. Translational control of hippocampal synaptic plasticity and memory by the eIF $2 \alpha$ kinase GCN2. Nature 436: 1166-1173.

Costa-Mattioli M, Gobert D, Stern E, Gamache K, Colina R, Cuello C, Sossin W, Kaufman R, Pelletier J, Rosenblum K, et al. 2007. eIF $2 \alpha$ phosphorylation bidirectionally regulates the switch from short- to long-term synaptic plasticity and memory. Cell 129: 195-206.

Costa-Mattioli M, Sossin WS, Klann E, Sonenberg N. 2009. Translational control of long-lasting synaptic plasticity and memory. Neuron 61: 10-26.

Cracco JB, Serrano P, Moskowitz SI, Bergold PJ, Sacktor TC. 2005. Protein synthesis-dependent LTP in isolated dendrites of CA1 pyramidal cells. Hippocampus 15: 551-556.

Crispino M, Kaplan BB, Martin R, Alvarez J, Chun JT, Benech JC, Giuditta A. 1997. Active polysomes are present in the large presynaptic endings of the synaptosomal fraction from squid brain. J Neurosci 17: 7694-7702.

Darnell JC, Richter JD. 2012. Cytoplasmic RNA-binding proteins and the control of complex brain function. Cold Spring Harb Perspect Biol 4: a012344.

Darnell JC, Van Driesche SJ, Zhang C, Hung KY, Mele A, Fraser CE, Stone EF, Chen C, Fak JJ, Chi SW, et al. 2011. FMRP stalls ribosomal translocation on mRNAs linked to synaptic function and autism. Cell 146: 247-261.

Dash PK, Hylin MJ, Hood KN, Orsi SA, Zhao J, Redell JB, Tsvetkov AS, Moore AN. 2015. Inhibition of eukaryotic initiation factor $2 \alpha$ phosphatase reduces tissue damage and improves learning and memory after experimental traumatic brain injury. J Neurotrauma 32: 1608-1620. 
Davidkova G, Carroll RC. 2007. Characterization of the role of microtubule-associated protein $1 \mathrm{~B}$ in metabotropic glutamate receptor-mediated endocytosis of AMPA receptors in hippocampus. J Neurosci 27: 13273-13278.

Davis HP, Squire LR. 1984. Protein synthesis and memory: A review. Psychol Bull 96: 518-559.

* Dever TE, Dinman JD, Green R. 2018. Translation elongation and recoding in eukaryotes. Cold Spring Harb Perspect Biol doi: 10.1101/cshperspect.a032649.

Di Prisco GV, Huang W, Buffington SA, Hsu CC, Bonnen PE, Placzek AN, Sidrauski C, Krnjevic K, Kaufman RJ, Walter P, et al. 2014. Translational control of mGluRdependent long-term depression and object-place learning by eIF2 $\alpha$. Nat Neurosci 17: 1073-1082.

Ehninger D, Han S, Shilyansky C, Zhou Y, Li W, Kwiatkowski DJ, Ramesh V, Silva AJ. 2008. Reversal of learning deficits in a $\mathrm{Tsc}^{+/-}$mouse model of tuberous sclerosis. Nat Med 14: 843-848.

El Fatimy R, Davidovic L, Tremblay S, Jaglin X, Dury A, Robert C, De Koninck P, Khandjian EW. 2016. Tracking the Fragile $\mathrm{X}$ mental retardation protein in a highly ordered neuronal ribonucleoparticles population: A link between stalled polyribosomes and RNA granules. PLoS Genet 12: e1006192.

Eom T, Muslimov IA, Tsokas P, Berardi V, Zhong J, Sacktor TC, Tiedge H. 2014. Neuronal BC RNAs cooperate with eIF4B to mediate activity-dependent translational control. J Cell Biol 207: 237-252.

Flexner LB, Flexner JB, Roberts RB. 1967. Memory in mice analyzed with antibiotics. Antibiotics are useful to study stages of memory and to indicate molecular events which sustain memory. Science 155: 1377-1383.

Frey U, Morris RG. 1998. Synaptic tagging: Implications for late maintenance of hippocampal long-term potentiation. Trends Neurosci 21: 181-188.

Gantois I, Khoutorsky A, Popic J, Aguilar-Valles A, Freemantle E, Cao R, Sharma V, Pooters T, Nagpal A, Skalecka A, et al. 2017. Metformin ameliorates core deficits in a mouse model of fragile X syndrome. Nat Med 23: 674677.

Gelinas JN, Nguyen PV. 2005. $\beta$-adrenergic receptor activation facilitates induction of a protein synthesis-dependent late phase of long-term potentiation. J Neurosci 25: 3294 3303.

Giustetto M, Hegde AN, Si K, Casadio A, Inokuchi K, Pei W, Kandel ER, Schwartz JH. 2003. Axonal transport of eukaryotic translation elongation factor $1 \alpha$ mRNA couples transcription in the nucleus to long-term facilitation at the synapse. Proc Natl Acad Sci 100: 1368013685 .

Gkogkas CG, Khoutorsky A, Ran I, Rampakakis E, Nevarko $T$, Weatherill $\mathrm{DB}$, Vasuta $\mathrm{C}$, Yee $\mathrm{S}$, Truitt $\mathrm{M}$, Dallaire P, et al. 2013. Autism-related deficits via dysregulated eIF4E-dependent translational control. Nature 493: 371-377.

Gkogkas CG, Khoutorsky A, Cao R, Jafarnejad SM, PragerKhoutorsky M, Giannakas N, Kaminari A, Fragkouli A, Nader K, Price TJ, et al. 2014. Pharmacogenetic inhibition of eIF4E-dependent Mmp9 mRNA translation reverses fragile X syndrome-like phenotypes. Cell Rep 9: 17421755.
Gobert D, Topolnik L, Azzi M, Huang L, Badeaux F, Desgroseillers L, Sossin WS, Lacaille JC. 2008. Forskolin induction of late-LTP and up-regulation of $5^{\prime}$ TOP mRNAs translation via mTOR, ERK, and PI3K in hippocampal pyramidal cells. J Neurochem 106: 1160-1174.

Graber TE, Hebert-Seropian S, Khoutorsky A, David A, Yewdell JW, Lacaille JC, Sossin WS. 2013. Reactivation of stalled polyribosomes in synaptic plasticity. Proc Natl Acad Sci 110: 16205-16210.

Graber TE, Freemantle E, Anadolu M, Hebert-Seropian S, MacAdam R, Shin U, Hoang HD, Alain T, Lacaille JC, Sossin WS. 2017. UPF1 governs synaptic plasticity through association with a STAU2 RNA granule. J Neurosci 37: 9116-9131.

Granger AJ, Shi Y, Lu W, Cerpas M, Nicoll RA. 2013. LTP requires a reserve pool of glutamate receptors independent of subunit type. Nature 493: 495-500.

Guzowski JF. 2002. Insights into immediate-early gene function in hippocampal memory consolidation using antisense oligonucleotide and fluorescent imaging approaches. Hippocampus 12: 86-104.

Heiman M, Schaefer A, Gong S, Peterson JD, Day M, Ramsey KE, Suarez-Farinas M, Schwarz C, Stephan DA, Surmeier DJ, et al. 2008. A translational profiling approach for the molecular characterization of CNS cell types. Cell 135: 738-748.

Heise C, Taha E, Murru L, Ponzoni L, Cattaneo A, Guarnieri FC, Montani C, Mossa A, Vezzoli E, Ippolito G, et al. 2017. eEF2K/eEF2 pathway controls the excitation/inhibition balance and susceptibility to epileptic seizures. Cereb Cortex 27: 2226-2248.

Hinnebusch AG, Ivanov IP, Sonenberg N. 2016. Translational control by $5^{\prime}$-untranslated regions of eukaryotic mRNAs. Science 352: 1413-1416.

Hoozemans JJ, Veerhuis R, Van Haastert ES, Rozemuller JM, Baas F, Eikelenboom P, Scheper W. 2005. The unfolded protein response is activated in Alzheimer's disease. Acta Neuropathol 110: 165-172.

Hou L, Antion MD, Hu D, Spencer CM, Paylor R, Klann E. 2006. Dynamic translational and proteasomal regulation of fragile $\mathrm{X}$ mental retardation protein controls mGluR-dependent long-term depression. Neuron 51: 441-454.

Hsieh AC, Liu Y, Edlind MP, Ingolia NT, Janes MR, Sher A, Shi EY, Stumpf CR, Christensen C, Bonham MJ, et al. 2012. The translational landscape of mTOR signalling steers cancer initiation and metastasis. Nature 485: 5561.

Hu J, Ferguson L, Adler K, Farah CA, Hastings MH, Sossin WS, Schacher S. 2017. Selective erasure of distinct forms of long-term synaptic plasticity underlying different forms of memory in the same postsynaptic neuron Curr Biol 27: 1888-1899.e1884.

Huang F, Chotiner JK, Steward O. 2005. The mRNA for elongation factor $1 \alpha$ is localized in dendrites and translated in response to treatments that induce long-term depression. J Neurosci 25: 7199-7209.

Huang W, Zhu PJ, Zhang S, Zhou H, Stoica L, Galiano M, Krnjevic K, Roman G, Costa-Mattioli M. 2013. mTORC2 controls actin polymerization required for consolidation of long-term memory. Nat Neurosci 16: 441-448. 
W.S. Sossin and M. Costa-Mattioli

Huang W, Placzek AN, Viana Di Prisco G, Khatiwada S, Sidrauski C, Krnjevic K, Walter P, Dani JA, Costa-Mattioli M. 2016. Translational control by eIF2 $\alpha$ phosphorylation regulates vulnerability to the synaptic and behavioral effects of cocaine. eLife 5: e12052.

Huber KM, Kayser MS, Bear MF. 2000. Role for rapid dendritic protein synthesis in hippocampal mGluRdependent long-term depression. Science 288: 12541257.

Huber KM, Klann E, Costa-Mattioli M, Zukin RS. 2015. Dysregulation of mammalian target of rapamycin signaling in mouse models of autism. J Neurosci 35: 1383613842 .

Im HI, Nakajima A, Gong B, Xiong X, Mamiya T, Gershon ES, Zhuo M, Tang YP. 2009. Post-training dephosphorylation of eEF-2 promotes protein synthesis for memory consolidation. PLoS ONE 4: e7424.

Inamura N, Nawa H, Takei N. 2005. Enhancement of translation elongation in neurons by brain-derived neurotrophic factor: Implications for mammalian target of rapamycin signaling. J Neurochem 95: 1438-1445.

* Ingolia NT, Hussmann JA, Weissman JS. 2018. Ribosome profiling: Global views of translation. Cold Spring Harb Perspect Biol doi: 10.1101/cshperspect.a032698.

Ishimura R, Nagy G, Dotu I, Zhou H, Yang XL, Schimmel P, Senju S, Nishimura Y, Chuang JH, Ackerman SL. 2014. RNA function. Ribosome stalling induced by mutation of a CNS-specific tRNA causes neurodegeneration. Science 345: 455-459.

Jiang Z, Belforte JE, Lu Y, Yabe Y, Pickel J, Smith CB, Je HS, Lu B, Nakazawa K. 2010. eIF2 $\alpha$ phosphorylation-dependent translation in CA1 pyramidal cells impairs hippocampal memory consolidation without affecting general translation. J Neurosci 30: 2582-2594.

Josselyn SA, Kohler S, Frankland PW. 2015. Finding the engram. Nat Rev Neurosci 16: 521-534.

Ju W, Morishita W, Tsui J, Gaietta G, Deerinck TJ, Adams SR, Garner CC, Tsien RY, Ellisman MH, Malenka RC. 2004. Activity-dependent regulation of dendritic synthesis and trafficking of AMPA receptors. Nat Neurosci 7: 244-253.

Jung H, Yoon BC, Holt CE. 2012. Axonal mRNA localization and local protein synthesis in nervous system assembly, maintenance and repair. Nat Rev Neurosci 13: 308324.

Kang H, Schuman EM. 1996. A requirement for local protein synthesis in neurotrophin-induced hippocampal synaptic plasticity. Science 273: 1402-1406.

Kapur M, Monaghan CE, Ackerman SL. 2017. Regulation of mRNA translation in neurons-A matter of life and death. Neuron 96: 616-637.

Kaul G, Pattan G, Rafeequi T. 2011. Eukaryotic elongation factor-2 (eEF2): Its regulation and peptide chain elongation. Cell Biochem Funct 29: 227-234.

Kelleher RJ III, Bear MF. 2008. The autistic neuron: Troubled translation? Cell 135: 401-406.

Kelleher RJ III, Govindarajan A, Jung HY, Kang H, Tonegawa S. 2004. Translational control by MAPK signaling in long-term synaptic plasticity and memory. Cell 116: 467479.
Kenney JW, Genheden M, Moon KM, Wang X, Foster LJ, Proud CG. 2016. Eukaryotic elongation factor 2 kinase regulates the synthesis of microtubule-related proteins in neurons. J Neurochem 136: 276-284.

Langstrom NS, Anderson JP, Lindroos HG, Winblad B, Wallace WC. 1989. Alzheimer's disease-associated reduction of polysomal mRNA translation. Brain Res Mol Brain Res 5: 259-269.

Laplante M, Sabatini DM. 2012. mTOR signaling in growth control and disease. Cell 149: 274-293.

Liu HH, Cline HT. 2016. Fragile X mental retardation protein is required to maintain visual conditioning-induced behavioral plasticity by limiting local protein synthesis. $J$ Neurosci 36: 7325-7339.

Liu K, Hu JY, Wang D, Schacher S. 2003. Protein synthesis at synapse versus cell body: Enhanced but transient expression of long-term facilitation at isolated synapses. J Neurobiol 56: 275-286.

Lourenco MV, Clarke JR, Frozza RL, Bomfim TR, FornyGermano L, Batista AF, Sathler LB, Brito-Moreira J, Amaral OB, Silva CA, et al. 2013. TNF- $\alpha$ mediates PKR-dependent memory impairment and brain IRS-1 inhibition induced by Alzheimer's $\beta$-amyloid oligomers in mice and monkeys. Cell Metab 18: 831-843.

Lugo JN, Smith GD, Morrison JB, White J. 2013. Deletion of PTEN produces deficits in conditioned fear and increases fragile X mental retardation protein. Learn Mem 20: 670673.

Ma T, Trinh MA, Wexler AJ, Bourbon C, Gatti E, Pierre P, Cavener DR, Klann E. 2013. Suppression of eIF2 $\alpha$ kinases alleviates Alzheimer's disease-related plasticity and memory deficits. Nat Neurosci 16: 1299-1305.

Ma T, Chen Y, Vingtdeux V, Zhao H, Viollet B, Marambaud P, Klann E. 2014. Inhibition of AMP-activated protein kinase signaling alleviates impairments in hippocampal synaptic plasticity induced by amyloid $\beta$. J Neurosci 34: 12230-12238.

Malenka RC, Bear MF. 2004. LTP and LTD: An embarrassment of riches. Neuron 44: 5-21.

Martin KC, Kosik KS. 2002. Synaptic tagging-Who's it? Nat Rev Neurosci 3: 813-820.

Martin KC, Barad M, Kandel ER. 2000. Local protein synthesis and its role in synapse-specific plasticity. Curr Opin Neurobiol 10: 587-592.

Mayford M, Siegelbaum SA, Kandel ER. 2012. Synapses and memory storage. Cold Spring Harb Perspect Biol 4: a005751.

Mazroui R, Huot ME, Tremblay S, Filion C, Labelle Y, Khandjian EW. 2002. Trapping of messenger RNA by Fragile X mental retardation protein into cytoplasmic granules induces translation repression. Hum Mol Genet 11: 3007-3017.

McCamphill PK, Farah CA, Anadolu MN, Hoque S, Sossin WS. 2015. Bidirectional regulation of eEF2 phosphorylation controls synaptic plasticity by decoding neuronal activity patterns. J Neurosci 35: 4403-4417.

McCamphill PK, Ferguson L, Sossin WS. 2017. A decrease in eukaryotic elongation factor 2 phosphorylation is required for local translation of sensorin and long-term facilitation in Aplysia. J Neurochem 142: 246-259. 
* Merrick WC, Pavitt GD. 2018. Protein synthesis initiation in eukaryotic cells. Cold Spring Harb Perspect Biol doi: 10.1101/chperspect.a033092.

Miller S, Yasuda M, Coats JK, Jones Y, Martone ME, Mayford M. 2002. Disruption of dendritic translation of CaMKII $\alpha$ impairs stabilization of synaptic plasticity and memory consolidation. Neuron 36: 507-519.

Moerke NJ, Aktas H, Chen H, Cantel S, Reibarkh MY Fahmy A, Gross JD, Degterev A, Yuan J, Chorev M, et al. 2007. Small-molecule inhibition of the interaction between the translation initiation factors eIF4E and eIF4G. Cell 128: 257-267.

Moreno JA, Radford H, Peretti D, Steinert JR, Verity N, Martin MG, Halliday M, Morgan J, Dinsdale D, Ortori CA, et al. 2012. Sustained translational repression by eIF2 $\alpha-P$ mediates prion neurodegeneration. Nature 485: 507-511.

Muslimov IA, Nimmrich V, Hernandez AI, Tcherepanov A, Sacktor TC, Tiedge H. 2004. Dendritic transport and localization of protein kinase $\mathrm{M} \zeta$ mRNA: Implications for molecular memory consolidation. J Biol Chem 279: 52613-52622.

Nairn AC, Palfrey HC. 1987. Identification of the major $M_{t}$ 100,000 substrate for calmodulin-dependent protein kinase III in mammalian cells as elongation factor-2. J Biol Chem 262: 17299-17303.

Neves G, Cooke SF, Bliss TV. 2008. Synaptic plasticity, memory and the hippocampus: A neural network approach to causality. Nat Rev Neurosci 9: 65-75.

Nosyreva ED, Huber KM. 2006. Metabotropic receptor-dependent long-term depression persists in the absence of protein synthesis in the mouse model of fragile X syndrome. J Neurophysiol 95: 3291-3295.

Okada D, Ozawa F, Inokuchi K. 2009. Input-specific spine entry of soma-derived Vesl-1S protein conforms to synaptic tagging. Science 324: 904-909.

Ostroff LE, Botsford B, Gindina S, Cowansage KK, LeDoux JE, Klann E, Hoeffer C. 2017. Accumulation of polyribosomes in dendritic spine heads, but not bases and necks, during memory consolidation depends on capdependent translation initiation. J Neurosci 37: 18621872.

Ounallah-Saad H, Sharma V, Edry E, Rosenblum K. 2014. Genetic or pharmacological reduction of PERK enhances cortical-dependent taste learning. J Neurosci 34: 1462414632 .

Ouyang Y, Rosenstein A, Kreiman G, Schuman EM, Kennedy MB. 1999. Tetanic stimulation leads to increased accumulation of $\mathrm{Ca}^{2+} /$ calmodulin-dependent protein kinase II via dendritic protein synthesis in hippocampal neurons. J Neurosci 19: 7823-7833.

Page G, Rioux Bilan A, Ingrand S, Lafay-Chebassier C, Pain S, Perault Pochat MC, Bouras C, Bayer T, Hugon J. 2006. Activated double-stranded RNA-dependent protein kinase and neuronal death in models of Alzheimer's disease. Neuroscience 139: 1343-1354.

Panja D, Dagyte G, Bidinosti M, Wibrand K, Kristiansen AM, Sonenberg N, Bramham CR. 2009. Novel translational control in Arc-dependent long term potentiation consolidation in vivo. J Biol Chem 284: 3149831511.
Park S, Park JM, Kim S, Kim JA, Shepherd JD, SmithHicks CL, Chowdhury S, Kaufmann W, Kuhl D, Ryazanov AG, et al. 2008. Elongation factor 2 and fragile $X$ mental retardation protein control the dynamic translation of Arc/Arg3.1 essential for mGluR-LTD. Neuron 59: $70-83$

Placzek AN, Prisco GV, Khatiwada S, Sgritta M, Huang W, Krnjevic K, Kaufman RJ, Dani JA, Walter P, Costa-Mattioli M. 2016. eIF2 $\alpha$-mediated translational control regulates the persistence of cocaine-induced LTP in midbrain dopamine neurons. eLife 5: e17517.

Proud CG. 2015. Regulation and roles of elongation factor 2 kinase. Biochem Soc Trans 43: 328-332.

* Proud CG. 2018. Phosphorylation and signal transduction pathways in translational control. Cold Spring Harb Perspect Biol doi: 10.1101/cshperspect.a033050.

Ramachandran B, Frey JU. 2009. Interfering with the actin network and its effect on long-term potentiation and synaptic tagging in hippocampal CA1 neurons in slices in vitro. J Neurosci 29: 12167-12173.

Ran I, Laplante I, Bourgeois C, Pepin J, Lacaille P, CostaMattioli M, Pelletier J, Sonenberg N, Lacaille JC. 2009. Persistent transcription- and translation-dependent long-term potentiation induced by mGluR1 in hippocampal interneurons. J Neurosci 29: 5605-5615.

Rangaraju V, Tom Dieck S, Schuman EM. 2017. Local translation in neuronal compartments: How local is local? EMBO Rep 18: 693-711.

Reijmers L, Mayford M. 2009. Genetic control of active neural circuits. Front Mol Neurosci 2: 27.

Richter JD, Coller J. 2015. Pausing on polyribosomes: Make way for elongation in translational control. Cell 163: 292300.

Ryan TJ, Roy DS, Pignatelli M, Arons A, Tonegawa S. 2015. Memory. Engram cells retain memory under retrograde amnesia. Science 348: 1007-1013.

Sajikumar S, Navakkode S, Sacktor TC, Frey JU. 2005. Synaptic tagging and cross-tagging: The role of protein kinase $\mathrm{M} \zeta$ in maintaining long-term potentiation but not longterm depression. J Neurosci 25: 5750-5756.

Sajikumar S, Navakkode S, Frey JU. 2007. Identification of compartment- and process-specific molecules required for "synaptic tagging" during long-term potentiation and long-term depression in hippocampal CA1. J Neurosci 27: 5068-5080.

Sanhueza M, Lisman J. 2013. The CaMKII/NMDAR complex as a molecular memory. Mol Brain 6: 10 .

Santini E, Huynh TN, MacAskill AF, Carter AG, Pierre P, Ruggero D, Kaphzan H, Klann E. 2013. Exaggerated translation causes synaptic and behavioural aberrations associated with autism. Nature 493: 411-415.

Santos RX, Correia SC, Cardoso S, Carvalho C, Santos MS, Moreira PI. 2011. Effects of rapamycin and TOR on aging and memory: Implications for Alzheimer's disease. J Neurochem 117: 927-936.

Sasikumar AN, Perez WB, Kinzy TG. 2012. The many roles of the eukaryotic elongation factor 1 complex. Wiley Interdiscip Rev RNA 3: 543-555.

Scheetz AJ, Nairn AC, Constantine-Paton M. 2000. NMDA receptor-mediated control of protein synthesis at developing synapses. Nat Neurosci 3: 211-216. 
W.S. Sossin and M. Costa-Mattioli

Segev Y, Barrera I, Ounallah-Saad H, Wibrand K, Sporild I, Livne A, Rosenberg T, David O, Mints M, Bramham CR, et al. 2015. PKR inhibition rescues memory deficit and ATF4 overexpression in ApoE 84 human replacement mice. J Neurosci 35: 12986-12993.

Sen T, Gupta R, Kaiser H, Sen N. 2017. Activation of PERK elicits memory impairment through inactivation of CREB and downregulation of PSD95 after traumatic brain injury. J Neurosci 37: 5900-5911.

Sidrauski C, Acosta-Alvear D, Khoutorsky A, Vedantham P, Hearn BR, Li H, Gamache K, Gallagher CM, Ang KK, Wilson C, et al. 2013. Pharmacological brake-release of mRNA translation enhances cognitive memory. eLife 2: e00498.

Sonenberg N, Hinnebusch AG. 2009. Regulation of translation initiation in eukaryotes: Mechanisms and biological targets. Cell 136: 731-745.

Sossin WS, DesGroseillers L. 2006. Intracellular trafficking of RNA in neurons. Traffic 7: 1581-1589.

Sossin WS, Lacaille JC. 2010. Mechanisms of translational regulation in synaptic plasticity. Curr Opin Neurobiol 20: 450-456.

Sperow M, Berry RB, Bayazitov IT, Zhu G, Baker SJ, Zakharenko SS. 2012. Phosphatase and tensin homologue (PTEN) regulates synaptic plasticity independently of its effect on neuronal morphology and migration. J Physiol 590: 777-792.

Squire LR, Davis HP. 1981. The pharmacology of memory: A neurobiological perspective. Annu Rev Pharmacol Toxicol 21: 323-356.

Squire LR, Genzel L, Wixted JT, Morris RG. 2015. Memory consolidation. Cold Spring Harb Perspect Biol 7: a021766.

Stern E, Chinnakkaruppan A, David O, Sonenberg N, Rosenblum K. 2013. Blocking the eIF2 $\alpha$ kinase (PKR) enhances positive and negative forms of cortex-dependent taste memory. J Neurosci 33: 2517-2525.

Steward O, Farris S, Pirbhoy PS, Darnell J, Driesche SJ. 2014 Localization and local translation of Arc/Arg3.1 mRNA at synapses: Some observations and paradoxes. Front Mol Neurosci 7: 101.

Stoica L, Zhu PJ, Huang W, Zhou H, Kozma SC, CostaMattioli M. 2011. Selective pharmacogenetic inhibition of mammalian target of rapamycin complex I (mTORC1) blocks long-term synaptic plasticity and memory storage. Proc Natl Acad Sci 108: 3791-3796.

Sutton MA, Schuman EM. 2006. Dendritic protein synthesis, synaptic plasticity, and memory. Cell 127: 49-58.

Taha E, Gildish I, Gal-Ben-Ari S, Rosenblum K. 2013. The role of eEF2 pathway in learning and synaptic plasticity. Neurobiol Learn Mem 105: 100-106.

Takei N, Kawamura M, Ishizuka Y, Kakiya N, Inamura N, Namba H, Nawa H. 2009. Brain-derived neurotrophic factor enhances the basal rate of protein synthesis by increasing active eukaryotic elongation factor 2 levels and promoting translation elongation in cortical neurons. $J$ Biol Chem 284: 26340-26348.

Tang SJ, Reis G, Kang H, Gingras AC, Sonenberg N, Schuman EM. 2002. A rapamycin-sensitive signaling pathway contributes to long-term synaptic plasticity in the hippocampus. Proc Natl Acad Sci 99: 467-472.
Thoreen CC, Chantranupong L, Keys HR, Wang T, Gray NS, Sabatini DM. 2012. A unifying model for mTORC1-mediated regulation of mRNA translation. Nature 485: 109113.

Tonegawa S, Liu X, Ramirez S, Redondo R. 2015. Memory engram cells have come of age. Neuron 87: 918-931.

Trinh MA, Klann E. 2013. Translational control by eIF2 $\alpha$ kinases in long-lasting synaptic plasticity and long-term memory. Neurobiol Learn Mem 105: 93-99.

Trinh MA, Kaphzan H, Wek RC, Pierre P, Cavener DR, Klann E. 2012. Brain-specific disruption of the eIF $2 \alpha$ kinase PERK decreases ATF4 expression and impairs behavioral flexibility. Cell Rep 1: 676-688.

Trinh MA, Ma T, Kaphzan H, Bhattacharya A, Antion MD, Cavener DR, Hoeffer CA, Klann E. 2014. The eIF2 $\alpha$ kinase PERK limits the expression of hippocampal metabotropic glutamate receptor-dependent long-term depression. Learn Mem 21: 298-304.

Tsokas P, Grace EA, Chan P, Ma T, Sealfon SC, Iyengar R, Landau EM, Blitzer RD. 2005. Local protein synthesis mediates a rapid increase in dendritic elongation factor $1 \mathrm{~A}$ after induction of late long-term potentiation. $\mathrm{J} \mathrm{Neu-}$ rosci 25: 5833-5843.

Tsokas P, Ma T, Iyengar R, Landau EM, Blitzer RD. 2007. Mitogen-activated protein kinase upregulates the dendritic translation machinery in long-term potentiation by controlling the mammalian target of rapamycin pathway. J Neurosci 27: 5885-5894.

Twiss JL, Fainzilber M. 2009. Ribosomes in axonsScrounging from the neighbors? Trends Cell Biol 19: 236-243.

Udagawa T, Farny NG, Jakovcevski M, Kaphzan H, Alarcon JM, Anilkumar S, Ivshina M, Hurt JA, Nagaoka K, Nalavadi VC, et al. 2013. Genetic and acute CPEB1 depletion ameliorate fragile X pathophysiology. Nat Med 19: 14731477.

van Vliet AR, Garg AD, Agostinis P. 2016. Coordination of stress, $\mathrm{Ca}^{2+}$, and immunogenic signaling pathways by PERK at the endoplasmic reticulum. Biol Chem 397: 649-656.

Verpelli C, Piccoli G, Zibetti C, Zanchi A, Gardoni F, Huang K, Brambilla D, Di Luca M, Battaglioli E, Sala C. 2010. Synaptic activity controls dendritic spine morphology by modulating eEF2-dependent BDNF synthesis. J Neurosci 30: $5830-5842$.

von der Brelie C, Waltereit R, Zhang L, Beck H, Kirschstein T. 2006. Impaired synaptic plasticity in a rat model of tuberous sclerosis. Eur J Neurosci 23: 686-692.

Wang X, Li W, Williams M, Terada N, Alessi DR, Proud, CG. 2001. Regulation of elongation factor 2 kinase by p90(RSK1) and p70 S6 kinase. EMBO J 20, 43704379.

Wang DO, Kim SM, Zhao Y, Hwang H, Miura SK, Sossin WS, Martin KC. 2009. Synapse- and stimulus-specific local translation during long-term neuronal plasticity. Science 324: 1536-1540.

Wang R, McGrath BC, Kopp RF, Roe MW, Tang X, Chen $G$, Cavener DR. 2013. Insulin secretion and $\mathrm{Ca}^{2+}$ dynamics in $\beta$-cells are regulated by PERK (EIF2AK3) in concert with calcineurin. J Biol Chem 288: 3382433836 . 
Weatherill DB, McCamphill PK, Pethoukov E, Dunn TW, Fan X, Sossin WS. 2011. Compartment-specific, differential regulation of eukaryotic elongation factor 2 and its kinase within Aplysia sensory neurons. J Neurochem 117: 841-855.

* Wek RC. 2018. Role of e1F2 $\alpha$ kinases in translational control and adaptation to cellular stresses. Cold Spring Harb Perspect Biol doi: 10.1101/cshperspect.a032870.

Wullschleger S, Loewith R, Hall MN. 2006. TOR signaling in growth and metabolism. Cell 124: 471-484.

Xu T, Yu X, Perlik AJ, Tobin WF, Zweig JA, Tennant K, Jones T, Zuo Y. 2009. Rapid formation and selective stabilization of synapses for enduring motor memories. Nature 462: 915-919.

Yang G, Pan F, Gan WB. 2009. Stably maintained dendritic spines are associated with lifelong memories. Nature 462 : 920-924.
Younts TJ, Monday HR, Dudok B, Klein ME, Jordan BA, Katona I, Castillo PE. 2016. Presynaptic protein synthesis is required for long-term plasticity of GABA release. $\mathrm{Neu}$ ron 92: 479-492.

Zhu PJ, Huang W, Kalikulov D, Yoo JW, Placzek AN, Stoica L, Zhou H, Bell JC, Friedlander MJ, Krnjevic K, et al. 2011. Suppression of PKR promotes network excitability and enhanced cognition by interferon- $\gamma$-mediated disinhibition. Cell 147: 1384-1396.

Zhu S, McGrath BC, Bai Y, Tang X, Cavener DR. 2016. PERK regulates $\mathrm{Gq}$ protein-coupled intracellular $\mathrm{Ca}^{2+}$ dynamics in primary cortical neurons. Mol Brain 9: 87.

* Zu T, Pattamatta A, Ranum LPW. 2018. RAN translation in neurological diseases. Cold Spring Harb Perspect Biol doi: 10.1101/cshperspect.a033019. 


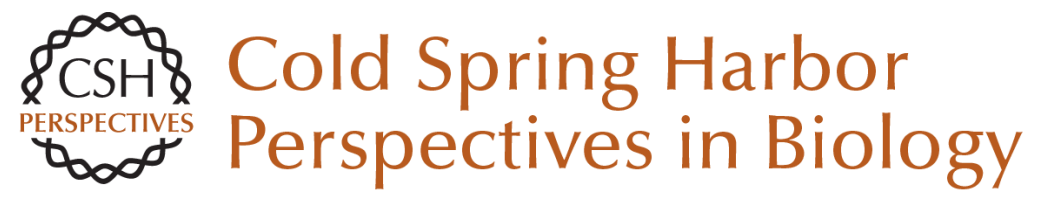

\section{Translational Control in the Brain in Health and Disease}

Wayne S. Sossin and Mauro Costa-Mattioli

Cold Spring Harb Perspect Biol 2019; doi: 10.1101/cshperspect.a032912 originally published online August 6, 2018

\section{Subject Collection Translation Mechanisms and Control}

Protein Synthesis and Translational Control: A Historical Perspective

Soroush Tahmasebi, Nahum Sonenberg, John W.B. Hershey, et al.

Translational Control in the Brain in Health and Disease

Wayne S. Sossin and Mauro Costa-Mattioli

Phosphorylation and Signal Transduction

Pathways in Translational Control Christopher G. Proud

Translational Control during Developmental Transitions

Felipe Karam Teixeira and Ruth Lehmann

Stress Granules and Processing Bodies in

Translational Control

Pavel Ivanov, Nancy Kedersha and Paul Anderson

Fluorescence Imaging Methods to Investigate

Translation in Single Cells

Jeetayu Biswas, Yang Liu, Robert H. Singer, et al.

Translational Control in Virus-Infected Cells Noam Stern-Ginossar, Sunnie R. Thompson, Michael B. Mathews, et al.

Nonsense-Mediated mRNA Decay Begins Where Translation Ends

Evangelos D. Karousis and Oliver Mühlemann
Principles of Translational Control John W.B. Hershey, Nahum Sonenberg and Michael B. Mathews

The Epitranscriptome in Translation Regulation Eyal Peer, Sharon Moshitch-Moshkovitz, Gideon Rechavi, et al.

Translational Control in Cancer Nathaniel Robichaud, Nahum Sonenberg, Davide Ruggero, et al.

Roles of Long Noncoding RNAs and Circular

RNAs in Translation Marina Chekulaeva and Nikolaus Rajewsky

Ribosome Profiling: Global Views of Translation Nicholas T. Ingolia, Jeffrey A. Hussmann and Jonathan S. Weissman

Noncanonical Translation Initiation in Eukaryotes Thaddaeus Kwan and Sunnie R. Thompson

Mechanistic Insights into MicroRNA-Mediated Gene Silencing Thomas F. Duchaine and Marc R. Fabian

Toward a Kinetic Understanding of Eukaryotic Translation Masaaki Sokabe and Christopher S. Fraser

For additional articles in this collection, see http://cshperspectives.cshlp.org/cgi/collection/

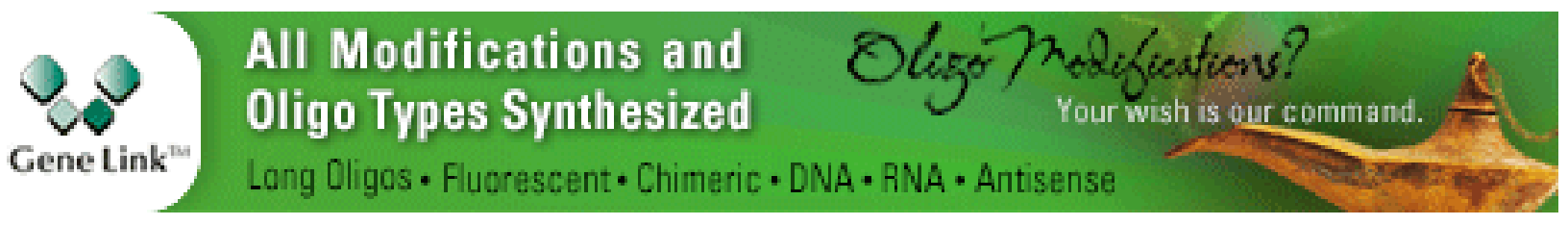

